\title{
LEAVES OF GRASS IN CLAUDE DEBUSSY'S PROSE
}

\author{
BRooks TOLIVER
}

The Wide-RAnging artistic SENSibilities of the French composer Claude Debussy (1862-1918) have prompted a staggering number of alleged connections; Javanese gamelon music, Spanish folk music, Japanese woodblock painting, English Pre-Raphaelitism, Impressionism and Symbolism are among the proposed influences on his music. ${ }^{1} \mathrm{His}$ prose-in the form of letters and critical writings on music-harbor phrases, paraphrases or hints of Charles Baudelaire, Jules Laforgue, John Ruskin and countless others. No one has yet added Walt Whitman to this list; while the absence of explicit reference to the American poet in Debussy's writings (and of his poetry in the remnant of Debussy's library auctioned off years after his death) seems to justify such inaction, I shall offer two related propositions: Debussy could not have avoided knowledge of Whitman had he tried, and his well-known nature aesthetic owes some-though by no means all-of its inspiration to that poet.

Whitman, "poète, philosophe, et 'roudy' " reached the Parisian reading public's attention as early as $1861 .^{2}$ By the time of his death, French critic Téodor de Wyzewa could predict: "When in a few years, we will finally be clear of the nineteenth century, the critics charged with settling the accounts will be stupefied to have to record the enormous influence of Walt Whitman on our contemporary literary movement." 3 Although Wyzewa proceeded to backtrack somewhat on this assertion, the article as a whole affirms the poet's high profile. By 1900 French literary columnists had featured Whitman in at least twenty-four articles and had published nearly as many poems from Leaves of Grass in translation. ${ }^{4}$ In approximately the first decade of the twentieth century, the preoccupation of the French with Whitman increased; this relatively short period saw the publication of another twenty-four Whitmanrelated articles as well as an entire book. ${ }^{5}$ From 1901-1908 about thirty of Whitman's poems appeared in French, and in 1909, Léon Bazalgette published his comprehensive translation of Leaves of Grass. ${ }^{6}$

This burst of Whitman-related activity in the twentieth century includes a series of articles by Henry Davray, at least one of which (the last) evidently caught Debussy's eye. ${ }^{7}$ As their titles announce, most of the poems translated in that final article concern music, and the follow- 
ing three prefigure certain of Debussy's aesthetic declarations: "Proud Music of the Storm," "That Music Always Round Me," and "Italian Music in Dakota." 8

Debussy drew upon the poetry of Whitman to plot the interrelationships of man, nature and music. Those familiar with Debussy's prose know that the composer repeatedly interprets nature's sounds as music. Neither he nor Whitman - who does so as well-can be said to have invented that manner of hearing. But the two stand together in the way that they elaborate upon the theme. In "Proud Music" Whitman describes the transformation of certain sounds into music:

Ah from a little child,

Thou knowest soul how to me all sounds became music,

The rain, the growing corn, the breeze among the long-leav'd corn,

The measure'd sea-surf beating on the sand,

The twittering bird, the hawk's sharp scream, . . . (405; ${ }^{9}$ emphasis added)

In an interview of 1911 Debussy made a nearly identical statement, and in the same enumerative rhetorical mode so characteristic of Whitman:

The sound of the sea, the outline of a horizon, the wind in the leaves, the cry of a birdthese set off complex impressions in us. And suddenly, without the consent of anyone on this earth, one of these memories bursts forth, expressing itself in the language of music. ${ }^{10}$ (emphasis added)

Whitman develops three related points in "That Music Always Round Me": these natural sounds surround the poet, they always have, and he has only recently begun to hear them as music:

That music always round me, unceasing, unbeginning, yet long untaught I did not hear, ...

. . . but now I think I begin to know them. ${ }^{11}$

(449 [lines 1, 9]; "them" refers to the voices of nature)

In response to a survey published in 1909 concerning contemporary music, Debussy reiterated this triple message:

We do not listen to the thousand noises of nature around us; we do not sufficiently watch out for the varied music that she offers us with such abundance. She envelops us and we have lived in her midst without perceiving her until now. ${ }^{12}$ (emphasis added)

Perhaps Debussy made his most thorough and enduring statements regarding nature and art in his conception of "open-air" music, published in La Revue blanche in June of 1901 and revised for Gil blas in January of 1903. ${ }^{13}$ "Proud Music" and "Italian Music" reverberate in those articles in at least four ways, all of which further the conception of music bonded with nature: 
1. Whitman and Debussy describe the removal of harmony from the concert hall to the outdoors:

Whitman, "Italian Music":

Subtler than ever, more harmony, as if born here, related here,

Not to the city's fresco'd rooms, not to the audience of the opera house, . . . (400)

\section{Debussy:}

. . . any harmonic progression that sounded stifled within the confines of a concert hall would take on a new significance [in the open air].

2. In Section 2 of "Proud Music" Whitman depicts a large organ around which children play. With its "hid footholds" and a "strong base" the organ resembles a tree:

Now the great organ sounds,

Tremulous, while underneath, (as the hid footholds of the earth,

On which arising rest, and leaping forth depend,

All shapes of beauty, grace and strength, all hues we know,

Green blades of grass and warbling birds, children that gambol and play, the clouds of heaven above, )

The strong base stands, and its pulsations intermits not, . . . (404)

Debussy too imagines a tree-organ where children would frolic:

And the tall, still tree trunks would not be left out: they would be the pipes of a universal organ. Hordes of children would play on their branches, singing the rounds of yesteryear, ...

3. Debussy describes music floating over the forest:

[Music] would float from the tops of the trees, through the light of the open air.

His development of the image elsewhere clarifies its origin in "Proud Music"; in a letter of 1911 (18 December) to his friend Robert Godet, he wrote:

No, what I'd much rather do is climb a mountain with you and listen to the wind . . . ! You may be sure it would sing only that music made of all the harmonies it gathers as it passes over the treetops (a sentence all the more beautiful for being entirely meaningless)! ${ }^{14}$

Three of the concepts presented in this passage-that of wind in the mountains, of wind in the treetops and of the music resulting from wind in the treetops-have predecessors in the third line of Whitman's poem, 
in the initial definition given for music of the storm: "Strong hum of forest tree-tops-wind of the mountains."

4. In "Italian Music" Whitman does not describe military music per se but rather nineteenth-century opera played by a military band. However, in translating the poem, Davray altered the subtitle, turning "the finest Regimental Band" into "la meilleure musique militaire" (see note 8). Hence in translation the first several lines read like a description of military music heard in the outdoors. As it drifts through the air engulfing rocks, woods, fort, etc., the music sounds "electric" and "artificial." Debussy begins his articles with criticism of military music heard in the open air, music which, "coming through the trees, sounds like a childhood phonograph." $" 15$

Debussy's two articles resemble "Proud Music" in other if less explicit ways. Both authors place the unification of man, music and nature in a utopian future; Debussy calls his vision a "dream for future generations" (first article) and Whitman's is a dream both in this sense-as the sixth section indicates-and literally, in that the poet describes what he dreams while sleeping to the sounds of a storm. An explicitly new type of orchestra comprises both authors' dreams: it is diverse and powerful, and it highlights the voice:

\section{Whitman:}

And with it [the "great organ"] every instrument in multitudes,

The players playing, all the world's musicians,

The solemn hymns and masses rousing adoration,

All passionate heart-chants, sorrowful appeals, . . . (405)

Give me to hold all sounds, (I madly struggling cry,)

Fill me with all the voices of the universe, . . . (409)

\section{Debussy:}

Imagine a large orchestra augmented with the sound of the human voice. (No, not a choral society, thank you!) Here would lie the embryo of music especially designed for the open air: new ideas flowing in broad lines both from the orchestra and voices. ${ }^{16}$

Although Davray published his translations slightly after Debussy's "plein-air" articles, the similarities suggest that the composer knew the translations before their publication or knew other translations of the same poems. Lacking archival documentation of a Debussy-Davray link, ${ }^{17}$ we must return to the more general issue of how Debussy learned of Whitman. The published translations and biographical articles mentioned earlier surely resulted from countless informal discussions and translations of Whitman's poetry. For instance, the Goncourt brothers 
recount in their memoirs how the writer Marcel Schwob forever carried with him Leaves of Grass from which he would translate at literary gatherings. ${ }^{18}$ Another writer penned these words twelve years before Bazalgette published his above-mentioned translations: "One knows from [Bazalgette] ardent translations of Walt Whitman, . . ."19

If we interpret these and other testaments of the period cautiously, we arrive at a fairly significant conclusion all the same, that in turn-ofthe-century Paris, most of the important writers knew of Whitman and admitted his influence on certain of their colleagues if not actually on themselves or on French literature as a whole. This sort of grudging acknowledgement characterizes the interviews that Percy Mansell Jones conducted in 1913-14 when he queried Parisian literary figures about Whitman. Francis Vielé-Griffin-American-born yet a long time Parisian resident and poet-carried denial to an extreme: he perceived no trace of Whitman in his own writing (nor in any French literature other than that of Claudel and Maeterlinck ${ }^{20}$ ) despite having himself previously published Whitman's autobiography and seven poems in translation, written the poet in hopes of translating Leaves of Grass in its entirety, ${ }^{21}$ and prompted the characterization by a colleague, "le petitfils de Walt Whitman."22 The same reticence may explain why Debussy himself never acknowledged a debt to Whitman.

Given the familiarity of the French with Whitman, the question of how exactly Debussy discovered him becomes both harder to answer and less important. I shall nevertheless suggest a few writers who may have offered Debussy a direct or indirect endorsement of Whitman. Jules Laforgue-whose poetry we know Debussy adored-had issued some of the first translations of Leaves of Grass in $1886 .{ }^{23}$ Further endorsements may have come from André Gide (Debussy's acquaintance if not truly a friend)-who openly esteemed Whitman and, in 1918, issued selections of Whitman's poetry translated by himself and others ${ }^{24}$ and from Claudel, who knew both Whitman's poetry and Debussy. ${ }^{25}$ Vielé-Griffin is yet another candidate; he published two of Debussy's own poems ("De rêve" and "De grève" from Proses lyriques) in the December 1892 "Lectures poétiques" corner of his journal Entretiens politiques et litterraires, having allotted the same space to Whitman in the preceding issue. Also, both Debussy and Vielé-Griffin attended some of poet Stéphane Mallarmé's “Tuesday-evening" literary gatherings around the late 1880s and early 1890 s, events at which Vielé-Griffin likely included discussions of Whitman. ${ }^{26}$

One other hint that Debussy knew of Whitman through VieléGriffin lies in the similarity between two of Debussy's letters and a poem by Whitman - "The World Below the Brine"-that Vielé-Griffin translated in $1888 .{ }^{27}$ In it Whitman depicts life-forms at the bottom of the sea (or "au fond de la mer" in French): 
The World below the brine,

Forests at the bottom of the sea, the branches and leaves, . . .

Sluggish existences grazing there suspended, or slowly crawling close to the bottom, ... (260)

Debussy also evoked images of sea life "au fond de la mer" for the purposes of conveying a sense of lethargy. In 1909 he described himself in this way to his friend and protégé André Caplet and then summarized: "I'm in the sort of mood where I'd rather be a sponge at the bottom of the sea . . ."28 To Godet in 1916 he used the same analogy to depict a drugged state: "In a cowardly way my thoughts go back to the morphine I used to take. It made me feel ill, but like a shell at the bottom of the sea." 29

While these proposed borrowings make the case for a WhitmanDebussy connection, they do not by themselves explain the significance of such a link; does Whitman's poetry figure into Debussy's music? Why did Debussy draw upon Whitman? Whitman might indeed have stimulated Debussy the composer, but I see no way of verifying that at the present; without the aid of exterior documentation such as shared titles or some sort of verbal testimony on Debussy's part, an interdisciplinary comparison of this sort would rest on generalizations regarding mood and subject matter that we more safely limit to Debussy's own milieu.

Several factors led Debussy to paraphrase Whitman. Foremost among them was a shift in French aesthetics that cast Whitman's poetry in a favorable light. Mallarmé's death in 1898 roughly coincides with the passing of what many younger writers understood as a certain tenor of Symbolism. Michel Décaudin, Kenneth Cornell and others have outlined this swing away from a perceived Symbolist artificiality, obscurity and elitism toward concepts embodied by a vocabulary that included "la nature," "la réalité," "la clarté" and "l'humanité."30 Erkkila has brought the subject to bear on Whitman, specifically on his attractiveness to French writers of the early twentieth century: whereas the Symbolists discussed his formal innovations, their immediate successors revered him for his healthy, robust spirit. ${ }^{31}$ Indeed, lines from "Proud Music" capture the mood of the times in which they were translated:

Let us go forth refresh'd amid the day,

Cheerfully tallying life, walking the world, the real,

Nourish'd henceforth by our celestial dream. (410)

The following group of quotations reinforces the point while entering Debussy into the discussion:

Whitman, "Song of the Open Road": 
Let the paper remain on the desk unwritten, and the book on the shelf unopen'd!

Maurice Le Blond (a young writer hostile to Symbolism), 1895:

The young people are deserting the museums, debating societies, and libraries for the sublime and tender teaching of Nature and of Life. ${ }^{32}$

Vielé-Griffin, describing a tendency of the younger writers, 1905:

. . . abandon "l'académisme" for the open air, the museum for nature. . . . ${ }^{33}$

Debussy, extract from the unpublished play Frères en art, 1895-1903?:

As for libraries . . . you will only find there changing aspects of the truth. Believe me, [truth] is not in the books; it's rather in the form or color of the sky! ${ }^{34}$

The latter quotation correctly places Debussy within the new aesthetics. The optimistic and natural tone of the "open-air" articles further situates him there as does his declared preference for watching the sunrise over hearing Beethoven's Pastoral symphony, ${ }^{35}$ his claim that one could learn orchestration better from the wind in the leaves than from treatises, ${ }^{36}$ and many other celebrated remarks. Debussy's relation to the new spirit is not as simple as I must present it here, but the complexity itself-had we the time to study it - would actually further the case at hand; briefly, Debussy had many friends among the Symbolists active in the 1890s and was often grouped with them - then and later-by his critics. This correctly suggests that he approached the new aesthetics from a distance. It further accounts for an uneasiness that shows in his occasional ambivalence toward its tenets, as well as-I argue - in his borrowings; Whitman's poetry offered him a model for reconceptualizing music.

Debussy's attraction to Whitman may also have been personal. Both Whitman and Debussy loved the ocean, as attested to by the poems of Whitman's "Sea-Drift" cluster among others and Debussy's La Mer and "Sirènes." 37 In the French press both sometimes suffered the image of an immoral sensualist and destroyer of tradition; in fact, both had their names turned into aberrations: "la Debussyte" had a counterpart in "la Whitmanomanie" (although it is not clear if the latter-like the former-was a sickness or merely a frenzy). ${ }^{38}$ Finally, Whitman extolled the virtues of lollygagging, while more than once in the first years of this century critics hinted at a connection between too much of this and Debussy's inability to follow his opera Pelléas et Mélisande (1902) with anything they judged equally substantial. In "Song of Myself" Whitman wrote: "I lean and loafe at my ease observ- 
ing a spear of summer grass" (28). Debussy counseled his stepson similarly: “. . . it's important to let your brain marinate under a hot sun. Spend time looking at flowers and snapshots. . . ."39

\section{University of California, Los Angeles}

\section{NOTES}

1 This study was presented at the national meeting of the American Musicological Society in Pittsburgh, November 1992.

2 Louis Etienne, "Whitman, poète, philosophe, 'rowdy,'" La Revue européene (1 November 1861), 104-117. Concerning Whitman's influence on late-nineteenth and early-twentieth century French writers, I have drawn my documentation primarily from Betsy Erkkila, Walt Whitman Among the French: Poet and Myth (Princeton, Princeton University Press, 1980), 239-255 (these pages contain most of the statistical material used in the present study). I have consulted the following studies as well: Michel Décaudin, La Crise des valeurs symbolistes (Paris: Privat éditeur, 1960), 357-359; Percy Mansell Jones, "Talks with French Poets in 1913-1914," French Studies 2 (1948), 201-222; Jones, "Whitman and the Symbolists," French Studies 2 (1948), 54-67; Jones, "Whitman and the Origins of Vers Libre," French Studies 2 (1948), 129-139.

3 Wyzewa, "Notes sur les littératures étrangères: Walt Whitman," Revue politique et littéraire (23 April 1892), 513 (translated by Erkkila, 51; discussed by Erkkila and by Jones, "Whitman and the Symbolists," 57-58).

4 The articles include seven eulogies from April through June of 1892.

5 Léon Bazalgette, Walt Whitman, l'homme et son oeuvre (Paris: Mercure de France, 1908).

6 Walt Whitman: Feuilles d'herbe (Paris: Mercure de France, 1909).

7 Henry Davray, "Walt Whitman: Specimen Days," L'Ermitage (December 1902), 401-419; (January 1903), 60-72; (February 1903), 112-133; (March 1903), 201-221. It is worth noting that the first article shared the issue with a very substantial and positive review of Debussy's opera: William Morland, "La Musique: reprise de Pelléas et Melisande," 471-476.

8 Below are Davray's translations of these poems (or in the case of the lengthy "Proud Music," merely the relevant passages of his translation), items inaccessible to many readers. The other music-related poems translated by Davray in the March article are "To a Certain Cantatrice" and "Vocalism."

H. Davray's Translations of 3 Poems by Whitman

(L'Ermitage, March 1903, pp. 201-221)

"Musique superbe de la tempête"

("Proud Music of the Storm")

Selections 
Musique superbe de la tempête,

Rafale qui court et bondit si libre, sifflant par les prairies,

Grande murmure des cîmes des forêts-vent des montagnes,

Vagues formes personnifiées-vous orchestres cachés,

5 Vous sérénades de fantômes aux instruments alertes,

Mêlant au rythme de la nature toutes les langues des nations,

Vous cordes, abandonnées comme par de vastes compositeurs-vous, choeurs,

Vous danses religieuses libres informes-vous de l'Orient,

Vous mi-voix des rivières, mugissement des cataractes dégringolantes,

10 Vous bruits des canons lointains avec la cavalerie galopante,

Echos des camps avec tous les différents appels de clairons,

Vous attroupant tumultueux, emplissant le minuit tardif, me courbant impuissant,

Entrant dans ma chambre de repos solitaire, pourqoui m'avez-vous saisis?

Maintenant le grand orgue résonne.

Frémissant, tandis que tout au bas (comme les points d'appui cachés de la terre,

35 Sur lesquels surgissantes reposent et desquels bondissantes dépendent,

Toutes formes de beauté, de grâce et de force, toutes les nuances que nous connaissons,

Les brins de gazon vert et les oiseaux gazouillants les enfants qui gambadent et jouent, les nuages du ciel là-haut),

La basse puissante se tient et ses pulsations ne s'interrompent pas,

Baignant, soutenant, noyant tout le reste, maternité de tout le reste

40 Et avec cela chaque instrument en multitudes,

Les musiciens jouant, les musiciens du monde entier,

Les hymnes et les messes solennelles stimulant l'adoration,

Tous les chants passionnés du coeur, les appels douloureux,

Les doux vocalistes improvisés des âges,

45 Et pour les mêler et les unir, le diapason de la terre,

[Davray deletes line 46]

Un nouvel orchestre composite, reliant les époques et les climats, dix fois rénovateur,

Comme des jours de jadis dont parlent les poètes, le Paradis,

L'exclusion, la longue séparation, mais maintenant c'est fini d'errer,

50 Le voyage est achevé, le voyageur est arrivé au foyer,

Et l'homme et l'art avec la Nature se confondent de nouveau . . .

$\mathrm{Ah}$, depuis que j'étais un petit enfant,

60 Tu sais, mon âme, comment pour moi tous les bruits devinrent musique,

La voix de ma mère en berceuse ou en hymne,

(Les voix, les tendres voix, voix aimants du souvenir,

dernier miracle de tous, ô voix de ma très chère mère et de mes soeurs;)

La pluie, le blé qui croît, la brise parmi les blés aux longues feuilles, 
65 Le ressac venant battre réguilièrement le sable,

L'oiseau babillard, le cri aigu de l'épervier,

Les notes des oiseaux sauvages volant bas la nuit en route vers le nord et le sud,

Le psaume dans l'église de village, ou sous les bosquets d'arbres, le campement en plein air,

Le ménétrier dans la taverne, la chanson à reprises, les chants interminables des matelots,

70 Le bétail mugissant, les moutons bêlants, le coq chantant à l'aube . . .

Alors je m'éveillai doucement,

Et m'arrêtant, questionnant un instant la musique de mon rêve,

145 Et questionnant toutes ces réminiscences, la tempête dans sa furie,

Et tous les chants des sopranos et des ténors,

Et ces frénétiques danses orientales de ferveur religieuses,

Et les doux instruments variés, et le diapason des orgues,

Et toutes les plaintes naïves de l'amour, de la douleur et de la mort,

$150 \mathrm{Je}$ dis à mon âme curieuse et silencieuse, hors de lit de la chambre du repos:

Viens, car j'ai trouvé l'expication que je cherchais depuis si longtemps,

Sortons, rafraîchis, dans la clarté du jour,

Nous adaptant joyeusement à la vie, parcourant le monde, le réel,

Nourris désormais de notre rêve céleste.

155 Et je dis, de plus,

Peut-être ce que tu as entendu, ô âme, n'était pas le bruit des vents;

$\mathrm{Ni}$ le réve de la tempête qui fait rage, ni les ailes qui battent, ni le cri rauque de l'oiseau de mer,

Ni le vocalisme de l'Italie ensoleillée,

$\mathrm{Ni}$ le majestueux orgue germanique, ni le vaste concours des voix, ni les créateurs d'harmonies,

$160 \mathrm{Ni}$ les strophes des époux et des épouses, ni le bruit des soldats en marche,

$\mathrm{Ni}$ les flûtes, ni les harpes, ni les appels des clairons dans les camps,

Mais un nouveau rythme fait pour toi,

Poèmes jetant un pont sur le chemin de la Vie à la Mort, vaguement soutenu dans l'air nocturne, imprécis, non écrit,

Qui nous fait passer dans le plein jour et écrire.

"Musique Italienne à Dakota"

("Le XVIIe-La meilleure musique militaire que j'aie jamais entendu”)

("Italian Music in Dakota")

([“The Seventeenth-the finest Regimental Band I ever heard"])

Dans l'air doux du soir enveloppant tout,

Rochers, bois, fort, canons, sentinelles allant et venant, interminables solitudes,

En ondes suaves, avec les notes des flûtes et des cors,

Electrique, pensive, turbulente, artificielle,

5 (Cependant, s'adaptant étrangement même ici, significations inconnues encore,

Plus subtile que jamais, davantage d'harmonie, comme si née ici, originaire d'ici,

Et non pas aux salles à fresques des cités, ni à l'auditoire des salles d'opéra,

Sons, échos, accords errants, comme réellement ici chez eux, 
L'innocent amour de la Sonnambula, les trois d'angoisse de la Norma, et ton choeur extatique Poliuto;)

Rayonnant dans le couchant limpide, jaune et oblique

La musique, la musique italienne à Dakota.

Tandis que la nature, souveraine de ce royaume accidente,

Aux agues dans des enfoncements obscurs, barbares et dissimulés,

15 Reconnaissant des rapports si lointains qu'ils soient,

(Comme quelque vieille racine ou un coin de terre reconnait sa fleur ou son fruit dernier né,)

Ecoute ravie.

${ }^{\star}$ Davray has collapsed Whitman's lines 9 and 10 .

"Cette musique toujours autour de moi"

("That Music Always Round Me")

Cette musique toujours à l'entour de moi, sans fin ni commencement, que cependant je n'entendais pas, n'ayant pas appris à l'entendre,

Mais maintenant j'entends le choeur et je suis transporté,

J'entends un ténor, solide, montant avec vigueur et santé, avec de joyeuses notes d'aube,

Un soprano par intervalles voguant légèrement sur la cîme d'immenses vagues,

5 Une basse transparente frémissant délicieusement sous et à travers l'univers,

Les triomphants tutti, les plaintes funèbres avec les douces flûtes et les violons, de tout cela je m'emplis,

Je n'entends pas seulement les volumes de son, je suis ému par les significations exquises,

J' écoute les voix différentes s'enroulant, et se déroulant, rivalisant, luttant avec une véhémence furieuse pour s'exceller l'une l'autre en émotion;

Je ne pense pas que les exécutants se connaissent eux-mêmes, mais maintenant je pense que je commence à les connaître.

9 Citations of Whitman's poetry are from Leaves of Grass: Comprehensive Reader's Edition, ed. Harold W. Blodgett and Sculley Bradley (New York: New York University Press, 1965).

10 Henry Malherbe, interviewer, "M. Claude Debussy et Le Martyre de Saint Sébastien," Excelsior (11 February 1911; trans. Richard Langham Smith in Debussy on Music: The Critical Writings of the Great French Composer, ed. F. Lesure and Langham Smith [Ithaca: Cornell University Press, 1988], 248). In this essay I generally avoid comparisons involving vocabulary and syntax (and hence quote Whitman and Debussy in English). My decision reflects the fact that certain of Debussy's remarks reach us through the filter of an interviewer; thus we cannot be sure of their original form. Also, some of them originated several years after the publication of Davray's series and thereby give rise to the possibility that the composer spoke from memory or paraphrased intervening translations. In most cases I shall ground the comparison in the leastcorruptible turf, that of imagery.

11 An anecdote suggests the wide circulation of "That Music Always Round Me" among French littérateurs: in 1913 when André Gide solicited Paul Claudel to contribute translations to a publication of Whitman's poetry, Claudel apparently laid claim to 
this poem which he recalled despite having misplaced his copy of Leaves of Grass; he described his choice as a short poem with references to singers' voices such as tenor and contralto. While "That Music" contains no reference to a contralto, within its nine lines Whitman mentions a chorus, tenor, soprano, bass, and "different voices." Claudel, letter to Gide (11 February 1913; published in The Correspondence Between Paul Claudel and André Gide, 1899-1926, trans. J. Russell [New York: Pantheon, 1952], 195).

12 Borgex, interviewer, "La Musique d'aujourd'hui et celle de demain," Commoedia 4 (November 1909); reprinted in Monsieur Croche et autres écrits, ed. F. Lesure (Paris: Gallimard, 1971), 281.

13 Below is the slightly longer second article as translated in Debussy on Music, 93-94; unless stated otherwise, quotations in the body of this essay are of that article. For further history regarding the genesis of the articles, see François Lesure's introduction to Monsieur Croche et autres écrits, 9.

\section{"Thoughts on Music in the Open Air" Claude Debussy \\ (Trans. by Richard Langham Smith)}

I like to imagine more impromptu happenings that blend more completely with the natural surroundings. Isn't military music meant to relieve the tedium of long marches and to bring joy to the streets? It expresses the patriotism that burns in every heart, and it unites the quiet soul of the little pastry cook with the old gentleman who thinks of nothing but the Alsace-Lorraine question, yet never talks about it. Far be it from me to take away these noble privileges, but I must say that, coming through the trees, it sounds like a childhood phonograph.

Imagine a large orchestra augmented with the sound of the human voice. (No, not a choral society, thank you!) Here would lie the embryo of music especially designed for the open air: new ideas flowing in broad lines both from the orchestra and voices. It would float from the tops of the trees, through the light of the open air, and any harmonic progression that sounded stifled within the confines of a concert hall would certainly take on a new significance. Perhaps this is the answer to the question of how to rid music of all those petty mannerisms of form and tonality-arbitrary questions with which music is unfortunately encumbered.

It must be understood that it would mean working not with the "gross" but with the "grand." I don't mean that it should produce echoes by repeating huge clusters of sound ad nauseum, but that it should take advantage of them by using them to prolong the crowd's feeling of harmony. The mysterious collaboration between air currents, the movement of leaves, and the perfume of flowers would combine together in such a natural marriage with the music that it would seem to live in each one of them . . . And the tall, still tree trunks would not be left out: they would be the pipes of a universal organ. Hordes of children would play on their branches, singing the rounds of yesteryear, for which the feeble rhymes that disgrace our gardens and towns today make such a poor substitute. We might also rediscover counterpoint: something we have currently invested with the stiffness of a mandarin, but from which the old masters of the French Renaissance could raise a smile.

14 Trans. by Roger Nichols in Debussy Letters, ed. Lesure and Nichols (Cambridge: Harvard University Press, 1987), 251. The self-conscious disclaimer closing this passage 
suggests that Debussy deliberately adopted a tone. A similar disclaimer followed his earliest-surviving reference to "open-air" music: "I hope [Debussy's composition Nocturnes] will be open-air music that will vibrate in the breeze of Freedom's mighty wing. (Goodness, what fine writing! . . . )" Letter to publisher Georges Hartmann of 16 September 1898 (trans. in Debussy Letters, 100).

15 At yet another point, Debussy seems to respond pointedly to one of Whitman's evocations, this time of echoing music: Whitman, "Italian Music":

Sounds, echoes, wandering strains, as really here at home, ... .

Debussy:

I don't mean that ["open-air" music] should produce echoes by repeating huge clusters of sound ad nauseam, but that it should take advantage of them by using them to prolong the crowd's feeling of harmony.

16 Debussy's choice of words here ("concours de la voix humaine") echoes Davray's translation of line 123 ("vastes concours de voix") and line 159 ("le vaste concours des voix").

17 While no such documentation is likely to surface, Debussy could have met the critic in the 1890s through his friend Pierre Louÿs, as both Louÿs and Davray knew and admired Oscar Wilde during this period.

18 Edmond and Jules de Goncourt, fournal: mémoires de la vie littéraire (1891-1904), vol. 4, ed. R. Ricatte (Monaco: Impr. Nationale, 1956), 436 (cited in Erkkila, 105).

19 Maurice Le Blond, “' 'L'Internationale des poètes' par Léon Bazalgette,” La Revue naturiste (May 1897): 133.

20 Jones, "Talks with French Poets," 212-214; "Whitman and the Origins of the Vers Libre," 130.

21 Erkkila, 79-80.

22 Le Blond, Essai sur le Naturisme (Paris: Mecure de France, 1896), 103.

23 Whitman/Laforgue, "Les Brins d'herbe: traduit de l'étonnant poète americain Walt Whitman-Dédicaces," La Vogue 1 (June 1886): 325-328.

24 Gide (et al.), Walt Whitman: oeuvres choisies (Paris: Nouvelle Revue Française, 1918). For further reference to this publication, see note 11 .

25 At least three documents of Claudel's relationship with Debussy survive: Claudel's diary for 23 August 1914 reads: "Explosion of a bomb while having a drink chez Weber, myself, Fontaine, Lalo and Debussy." Claudel, Fournal, vol. 1, ed. F. Varillon and J. Petit (Paris: Gallimard, 1968-9), 298. In an interview of 1925 Claudel remembered the following: "For Connaissance du temps (1906) I had a note inserted in the Mercure saying that the work would be sent for free to whoever requested it. I received forty letters, among which was one from Claude Debussy whose warmth I never forgot." Reprinted in Cahiers Paul Claudel, vol. 6, ed. H. Micciollo and J. Petit (Paris: Nouvelle Revue Française, 1966), 225. Claudel wrote to René Peter in 1946: "I liked Debussy who was 
one of the first to contact me at my remote Consulate when no one [else] had the slightest idea of my existence!" (Peter, Le Théâtre et la vie sous la Troisième République: deuxième époque [Paris, Editions Marchot, 1947], 302).

26 Erkkila, 87.

27 Whitman/Vielé-Griffin, "Walt Whitman: poèmes: 'Visages,' 'A une locomotive en hiver,' 'Un Monde . . .,', "Revue Indépendante 9 (November 1888): 285-286.

28 Letter of 20 July (trans. in Debussy Letters, 208).

29 Letter of 11 December (trans. in Debussy Letters, 321-322).

30 Michel Décaudin, La Crise des valeurs symbolistes; Kenneth Cornell, The Symbolist Movement, Yale Romanic Studies, ser. 2, vol. 2 (New Haven: Yale University Press, 1951), 160-200; Cornell, The Post-Symbolist Period: French Poetic Currents, 1900-1920, Yale Romanic Studies, ser. 2, vol. 6 (New Haven: Yale University Press, 1958).

31 Erkkila, 97-98.

32 Trans. Erkkila, 99.

33 Vielé-Griffin, quoted in Georges Le Cardonnel and Charles Vellay, La Littérature contemporaine (1905): opinions des écrivains de ce temps (Paris: Société du Mercure de France, 1905), 68.

34 Debussy, Frères en art (cited by Edward Lockspeiser, "Frères en art: pièce de théâtre inédite de Debussy," Revue de musicologie 56/2 [1970]: 174). I have quoted these lines because they match the others so well; the fact that Debussy may have co-written them with René Peter need not detract from the thesis-amply supported below-that Debussy answered the call of the times.

35 Debussy, “L'Entretien avec M. Croche," La Revue blanche (1 July 1901; reprinted in Monsieur Croche, 51).

36 Letter to Charles Levadé of 4 September 1903 (trans. in Debussy Letters, 140).

37 This similarity may lie behind one appraisal of Debussy's La Mer: “. . . it almost suggests the possibility that some day we may have an Americanized Debussy." Gaston Carraud in La Liberté (17 October 1905; trans. by Maire and Grace O'Brien in Léon Vallas, Claude Debussy: His Life and Works [1927; New York: Dover Publications, 1973], 173). Carraud did not specify what about La Mer called to mind an "Americanized Debussy" much less what or who typified America. But his description of the "less subtle" atmosphere and "the rich wealth of sounds" (not to mention the oceanic subject) make Whitman a possible candidate since both the Americans and the French viewed his poetry as unrefined and colossal in spirit. This hunch gains credence when we recognize that by "Americanized" Carraud did not actually intend American music; earlier in the review he stated that the musical ideas themselves "suggest now the Russians, now César Franck." 
38 Camille Mauclair, "La 'Debussyte,'" Le Courrier musical (15 September 1905): 501-505; for reference to "la Whitmanomanie," see Davray's article of December 1902, 402.

39 Letter to Raoul Bardac of 24 February 1906 (trans. in Debussy Letters, 166). 